Provided for non-commercial research and education use. Not for reproduction, distribution or commercial use.

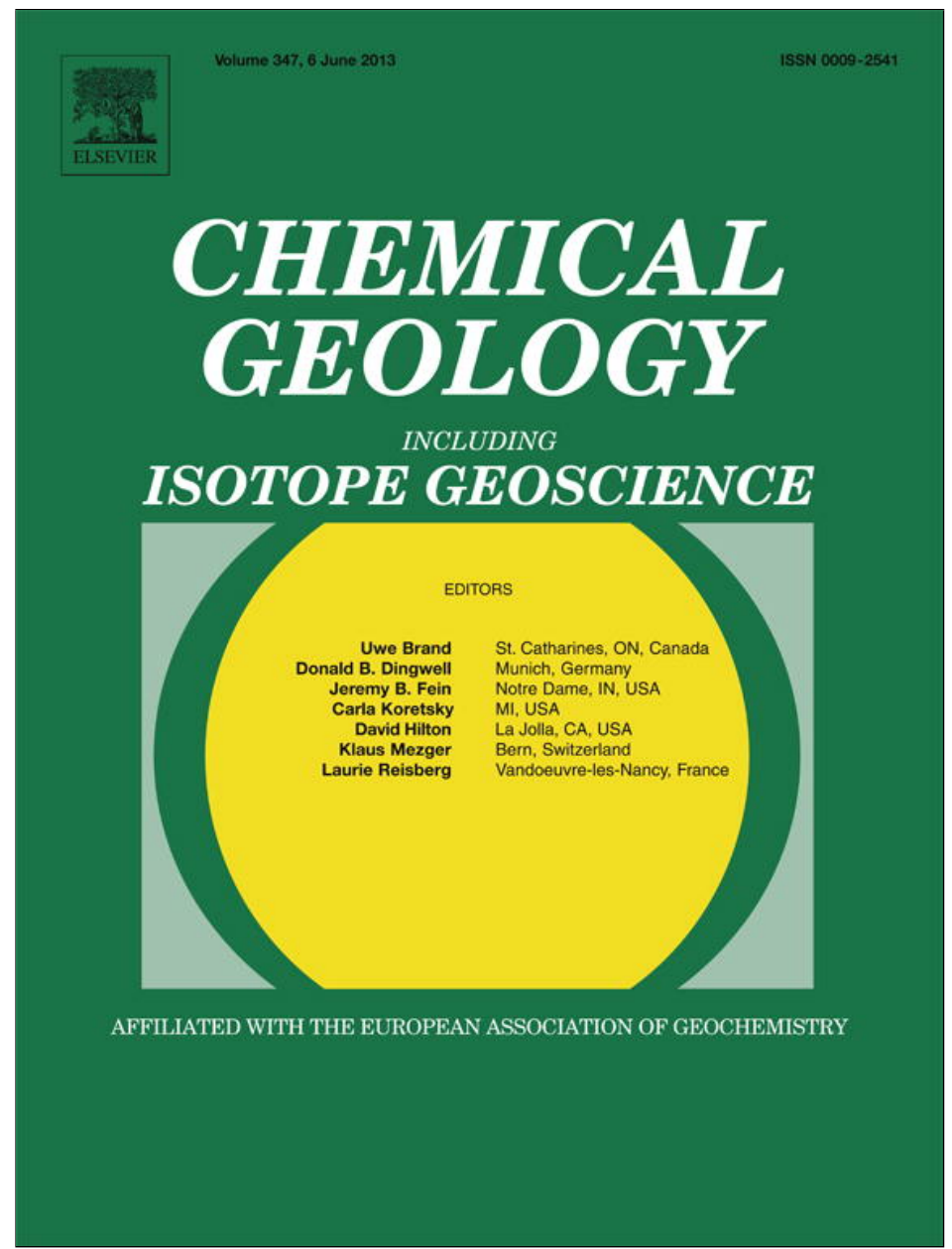

This article appeared in a journal published by Elsevier. The attached copy is furnished to the author for internal non-commercial research and education use, including for instruction at the authors institution and sharing with colleagues.

Other uses, including reproduction and distribution, or selling or licensing copies, or posting to personal, institutional or third party websites are prohibited.

In most cases authors are permitted to post their version of the article (e.g. in Word or Tex form) to their personal website or institutional repository. Authors requiring further information regarding Elsevier's archiving and manuscript policies are encouraged to visit:

http://www.elsevier.com/authorsrights 


\title{
Source of diagenetic fluids from fluid-inclusion gas ratios
}

\author{
Karem Azmy ${ }^{\text {a,* }}$, Nigel J.F. Blamey ${ }^{\text {a,b }}$ \\ a Department of Earth Sciences, Memorial University of Newfoundland, St. John's, NL, A1B 3X5, Canada \\ ${ }^{\mathrm{b}}$ Department of Earth Science, Brock University, St. Catharines, ON, L2S 3A1, Canada
}

\section{A R T I C L E I N F O}

\section{Article history:}

Received 3 January 2013

Received in revised form 18 March 2013

Accepted 10 April 2013

Available online 19 April 2013

Edited by David R. Hilton

\section{Keywords:}

Fluid-inclusion gas ratios

Origin of diagenetic carbonates

Source diagenetic fluids

\begin{abstract}
A B S T R A C T
Alteration of marine carbonates, such as those from the Mesoproterozoic and Lower Ordovician, during burial history is carried out by diagenetic fluids that could potentially have different sources. During precipitation diagenetic minerals may trap tiny amounts of those solutions in fluid inclusions, thus providing fossil archives and aliquots that offer valuable record about the origin of fluids. The analysis of various fluid-inclusion gases (e.g., $\mathrm{CH}_{4}, \mathrm{CO}_{2}, \mathrm{~N}_{2}$, He and $\mathrm{Ar}$ ) may provide reliable information which allows the discrimination among different fluid sources. Generally speaking, the meteoric cements should have $\mathrm{N}_{2} / \mathrm{Ar}$ ratio around 38 (the value for air-saturated water). However, the gases in inclusions of the current study, trapped by diagenetic carbonates (cements), from independent depositional basins of different ages (Mesoproterozoic, Early Ordovician, and Modern) and locations (Canada, USA, Brazil and Java Sea), have $\mathrm{N}_{2}$ /Ar ratios ( 92) which match non-magmatic (modified marine or meteoric) fluids. Also, the Ar/He ratios $(\sim 3)$ in the studied fluid inclusions are significantly lower than those of calc-alkaline magmatic fluids $(\geq 20)$, thus excluding magmatic fluids as a potential source. On the other hand, some $\mathrm{N}_{2} / \mathrm{Ar}$ and $\mathrm{Ar} / \mathrm{He}$ ratios of the studied samples approach values reported for basinal fluids from the Hansonburg MVT deposit in New Mexico (68 and 1, respectively), suggesting that both meteoric/mixed marine-meteoric (evolved meteoric) and basinal fluids may be involved during carbonate diagenesis.
\end{abstract}

(C) 2013 Elsevier B.V. All rights reserved.

\section{Introduction}

Marine carbonates are generally precipitated in metastable phases such as aragonite (A) and high magnesium calcite (HMC), which are stabilized into the diagenetic low magnesium calcite (LMC) through water-rock interaction during exposure to meteoric or deep burial conditions (Tucker and Wright, 1990). Also, dolomitization is a common diagenetic process, which may influence the original marine carbonates or the previously altered phase (LMC) and it occurs at early (e.g., near-surface dolomitization) and/or late (e.g., hydrothermal dolomitization) stages during the burial history of sediments (e.g., Lonnee and Machel, 2006). Traces of the diagenetic waters are trapped in the form of fluid inclusions in the crystals of the end product carbonate. Those inclusions work as time capsules that retain the chemical characteristics of the diagenetic fluid and the temperature of precipitation of the diagenetic carbonate phase (Goldstein and Reynolds, 1994). Also, those inclusions may trap traces of the gases that existed during diagenesis. The relative concentrations of these gases reveal significant information about the nature of the diagenetic fluid (e.g., basinal vs. magmatic) and environment to provide an additional verification tool of the conditions that dominated during the sediment burial history (e.g., Norman and Musgrave, 1994).

\footnotetext{
* Corresponding author.

E-mail addresses: kazmy@mun.ca, karem.azmy@gmail.com (K. Azmy).
}

The origin of fluids that drive diagenesis may at times remain debatable. Meteoric waters and basinal brines are potential fluids (e.g., Lavoie et al., 2005; Azmy et al., 2006; Lonnee and Machel, 2006; Azmy et al., 2008c, 2009; Conliffe et al., 2010) in addition to magmatic fluids (cf. Conliffe et al., 2010). Resolving the issue of the nature of diagenetic processes requires a multifaceted approach such as petrography, stable isotopes and trace element geochemistry, microthermometric studies and quantitative fluid-inclusion volatile analysis by mass spectrometry.

Fluid inclusions may be regarded as microscopic aliquots of a fluid that comprise possible combinations of liquid, gas or solid, trapped during mineral growth or by annealing of secondary fractures (Roedder, 1984). The most common inclusions in the current study are water with dissolved gases and salts. Salinity reported in diagenetic fluids of the investigated coarse-grained dolomite is up to 25 wt.\% $\mathrm{NaCl}$ equivalent (e.g., Azmy et al., 2008c, 2009; Conliffe et al., 2009, 2010). However, no microthermometric measurements were obtained from the dolomicrites because of the crystal near-micritic size and submicron inclusions. Petrography of the investigated dolomites and their 2-phase fluid inclusions have been recently studied and discussed in detail by Azmy et al. (2001, 2006, 2008a, 2008b, 2008c, 2009), Conliffe et al. (2009, 2010) and Azmy and Conliffe (2010), which makes these dolomites ideal candidates for a fluid-inclusion gas ratio investigation. Origin of dolomitizing fluids have been the focus of studies particularly because of the development of porosity associated with dolomites, which constitute a significant 
global hydrocarbon reservoirs. Earlier studies of gas ratios in fluid inclusions provided ranges of compositions characteristic of magmatic fluids and non-magmatic (possibly meteoric or mixed marinemeteoric) fluids (e.g., Moore et al., 1997; Blamey and Norman, 2002), which can be applied in the identification of the origin of dolomitizing fluids through the diagenetic history of basins. The main objective of the current study is to investigate the composition of gases in fluid inclusions of non-altered and altered carbonate phases (aragonite, calcites and dolomites) from different basins (Canada, USA, Brazil and Java Sea) and diagenetic settings (shallow and deep burial) in an attempt to discriminate the fluid sources for the examined carbonates, particularly those from the St. George Group hydrothermal dolomites, and test the reliability of ratios of dissolved gases in fluid inclusions for the reconstruction of their diagenetic environments. This study is fairly new and it utilizes a suite of samples that was already extensively screened with multitechniques (petrography and geochemistry). The samples cover a wide spectrum of depositional and diagenetic settings.

\section{Methods}

There are four principle ways to gain information about fluid inclusion gases (Blamey, 2012), which are by microthermometry, Raman spectroscopy, gas chromatography and mass spectrometry. Microthermometry and Raman spectroscopy require relatively large fluid inclusions and the gases to be in relatively high abundance and these methods provide information on a limited species range. However, both methods lack the reliable detection limits and ability to measure a larger species range. Gas chromatography has an excellent species range but requires a $5-10 \mathrm{~g}$ sample, thus limiting its ability to resolve sample heterogeneities. Fluid-inclusion gas analysis by mass spectrometry has a broad species range, analyzes for noble gases, produces quantitative data, and meanwhile has detection limits around $0.2 \mathrm{ppm}$ for a typical incremental crush. The ability to analyze samples as small as $25 \mathrm{mg}$, through the procedure utilized in the current study, has allowed minimizing problems with sample heterogeneities.

Fluid inclusion volatile analysis was done in vacuum using the CFS (crush-fast scan) method (Norman and Moore, 1997; Norman and Blamey, 2001; Parry and Blamey, 2010; Blamey, 2012) at the New Mexico Institute of Mining and Technology (NMT) Fluid Inclusion Gas laboratory. Unlike the conventional bulk thermal decrepitation method whereby all the inclusions are liberated to produce one analysis, the incremental crush method produces smaller bursts and hence increases information of potential sample heterogeneities if multiple fluid inclusion assemblages are present. Samples were first cleaned with $\mathrm{NaOH}$ to reduce surface organic contamination, then rinsed several times with deionized water, and dried at room temperature. Approximately $0.2 \mathrm{~g}$ of each sample was incrementally crushed under a vacuum of $\sim 10^{-8}$ Torr yielding five to eight crushes per sample. The vacuum is the equivalent of $\sim 10^{-11} \mathrm{~atm}$ and therefore the potential for air contamination is unlikely and opening inclusions in this high vacuum is orders of magnitude above background.

The analyses were performed by two Pfeiffer-Vacuum Prisma quadrupole mass spectrometers operating in fast-scan, peaking-hopping mode (Norman and Blamey, 2001). The system routinely reports the following gaseous species: $\mathrm{H}_{2}, \mathrm{He}, \mathrm{CH}_{4}, \mathrm{H}_{2} \mathrm{O}, \mathrm{N}_{2}, \mathrm{O}_{2}, \mathrm{Ar}$, and $\mathrm{CO}_{2}$. The instrument was calibrated using synthetic inclusions filled with Scott Gas mixtures, and three in-house fluid inclusion gas standards as described by Norman and Blamey (2001), Norman et al. (2002), Parry and Blamey (2010), and Blamey (2012). The concentration of each species was calculated by proprietary software to provide a quantitative analysis. Precision is better than $5 \%$ for major gaseous species and $0.2 \%$ for water/gas ratios based on natural fluid inclusion standards. The $3 \sigma$ detection limit varies for most species and is dependent on burst size, interference from other species, and instrument alignment but is approximately 0.2 ppm for He (Blamey, 2012; Blamey et al., 2012), which is comparable to the femtomole detection limit reported for gas chromatography (Bray et al., 1991).

The analyzed samples cover a wide spectrum of carbonates (Table 1) including well-preserved marine carbonates (modern aragonitic coral), altered sediments at near surface conditions (e.g., lime mudstones and dolomicrite) and late hydrothermal (fracture-filling) dolomite (Azmy et al., 2006, 2008a, 2008b; Azmy et al., 2009). The samples were globally selected from different sedimentary basins of different ages (Table 1 ) to examine the influence of age and burial conditions on the results. The purpose of including samples from the Mesoproterozoic Vazante dolomites is mainly to examine the influence of age on the investigated gas ratios since some of the investigated gases (e.g., He) can be produced by radiogenic decay of some elements such as $U$ and other radiogenic elements although the concentrations of those elements is significantly lower in carbonates $(\leq 0.5 \mathrm{ppm})$ compared with their counterparts in igneous rocks (cf. Norman and Musgrave, 1994). Also, the samples include organic-rich dolomicrites that had microbial (stromatolitic) lime mud precursor to investigate the influence of organic material on the fluid-inclusion gas ratios.

For comparison of fluid-inclusion gas ratio results, the fluorite $(\mathrm{F})$ fluid inclusion laboratory standard HF-1 available at New Mexico Tech was analyzed as a regular sample (example of an MVT deposit) and 28 measurements were performed. This standard from the Hansonburg Mississippi-Valley type deposit (MVT) in New Mexico was originally collected, described, and analyzed using the thermal decrepitation method of gas extraction by Norman et al. (1985). The origin of MVT deposits is known to be amagmatic but from a basinal brine fluid and/or highly modified seawater component (Chi and Savard, 1997; Stoffel et al., 2008). By reanalyzing the HF-1 standard using the newer incremental crush fast scan method, we can certainly compare the diagenetic carbonate data to material that hosts basinal fluids acquired by a similar mechanism.

The detailed petrography of the carbonate samples is described by Azmy et al. (2006, 2008a, 2008b, 2009) and summarized in Table 1. The crushed material, from each sample, was intentionally selected to contain only a single carbonate phase to avoid mixing of fluidinclusion gases released from different carbonates phases.

\section{Geologic setting and lithostratigraphy}

The nature of the sediments and diagenetic history have been well established through earlier studies of their detailed petrographic, microthermometric and geochemical attributes (e.g., Azmy et al., 2006; Knight et al., 2007; Azmy et al., 2008a, 2008c; Edinger et al., 2008; Knight et al., 2008; Azmy et al., 2009; Conliffe et al., 2009; Azmy and Conliffe, 2010; Conliffe et al., 2010, 2012; Conliffe et al., 2012). They include unaltered Modern aragonitic coral (A) from the Java Sea at Point Teluk Awur, near Jepara, Central Java (Azmy et al., 2008a; Edinger et al., 2008) and altered phases of marine carbonates, including lime mudstones (C1), late fracture-filling calcite (C3), dolomicrites (D1) of early diagenesis and late hydrothermal dolomites (D2 and D3, Table 1). The altered phases (hosted in lime mudstones and dolomites) were collected from two sequences (Lower Ordovician St. George Group in western Newfoundland, Canada and Mesoproterozoic Vazante sequence in east central Brazil) of different ages and from different sedimentary basins (Azmy et al., 2006; Knight et al., 2007; Azmy et al., 2008a, 2008b, 2008c; Knight et al., 2008; Azmy and Conliffe, 2010; Azomani et al., 2013).

The St. George Group consists of early Ordovician (TremadocArenig) platform carbonates ( $~ 500$ m-thick) which, from bottom to top, include the Watts Bight, Boat Harbour, Catoche, and Aguathuna formations (Fig. 1). The upper boundary of the St. George Group (Aguathuna/Table Point formations contact) is marked by the major regional St. George Group Unconformity (SGU, Fig. 1). The St. George Group can be divided into two sedimentary megacycles separated by the Boat Harbour Disconformity (BHD, Fig. 1). Each megacycle is 
Table 1

Description, location, petrography, homogenization temperatures $\left(\mathrm{T}_{h}\right)$ of primary fluid inclusions, and summary of quantitative fluid inclusion gas analyses (in mol\%) using a burst-size weighted mean of several replicate analyses from the investigated samples. The $T_{h}$ is the mean value of multiple measurements.

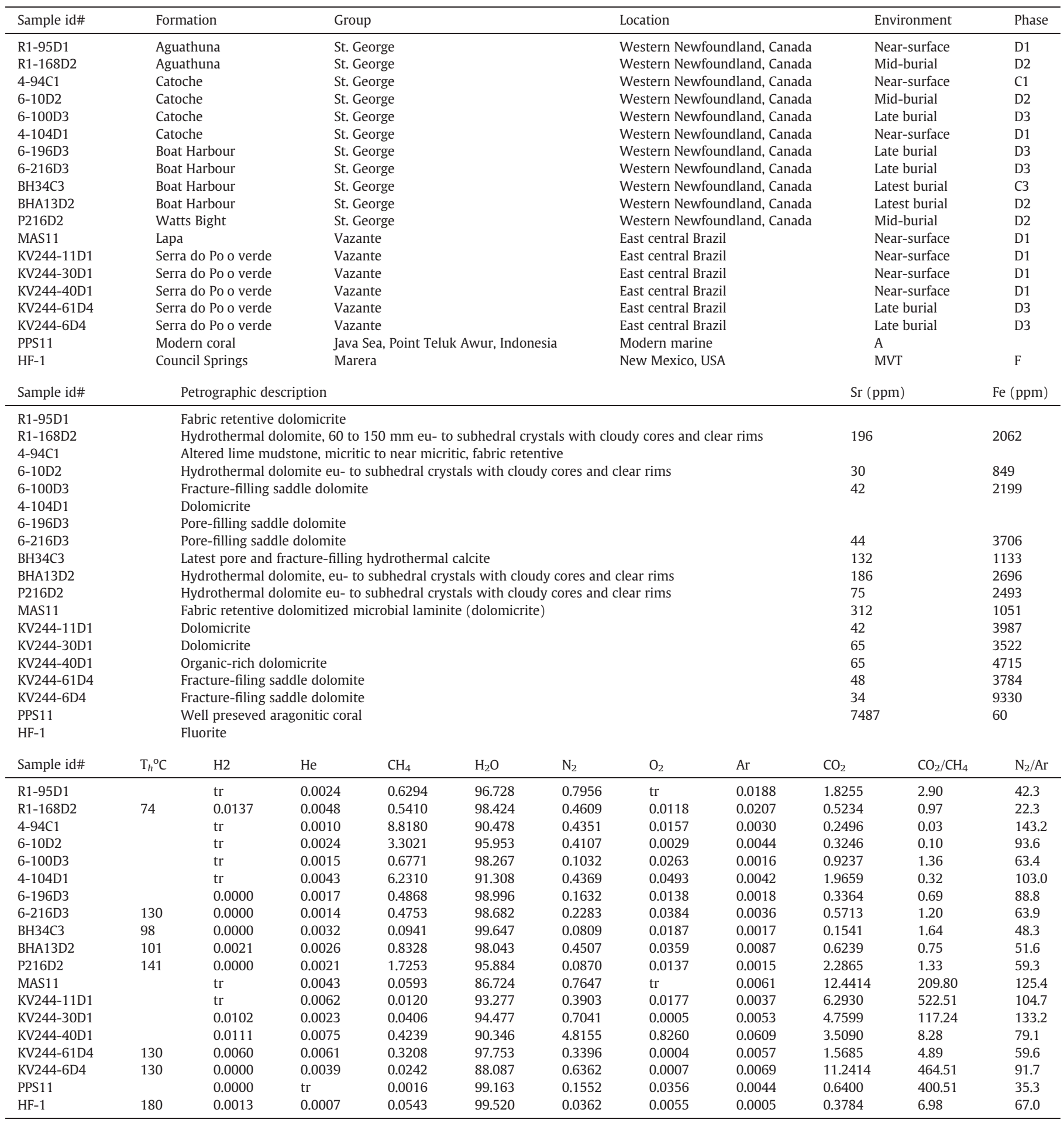

characterized by a large-scale transgressive-regressive succession that generally resulted in stacking of lower peritidal, middle subtidal and upper peritidal units (Knight and James, 1987; Knight et al., 2007, 2008). Multiple-stage dolomitization significantly affected the St. George Group carbonates (Knight et al., 2007; Azmy et al., 2008c; Knight et al., 2008). Three major phases of dolomitization (Table 1) have been identified in the St. George Group dolomites (Azmy et al., 2008a, 2008c, 2009; Azmy and Conliffe, 2010; Azomani et al., 2013), which include the early diagenesis (by mixed marine-meteoric waters) dolomicrite (D1) and the late burial hydrothermal D2 and D3 that were precipitated at elevated temperature (74 $141{ }^{\circ} \mathrm{C}$, Table 1$)$.

The Vazante rocks consists of Mesoproterozoic carbonate-dominated (mainly stromatolitic carbonate muds and rhythmites) platform deposits (Dardenne, 2001) that extend along more than $300 \mathrm{~km} \mathrm{~N}-\mathrm{S}$ in the external zone of the Brasilia Fold Belt in the São Francisco Basin of east central Brazil. The São Francisco Craton (SFC) consists of 


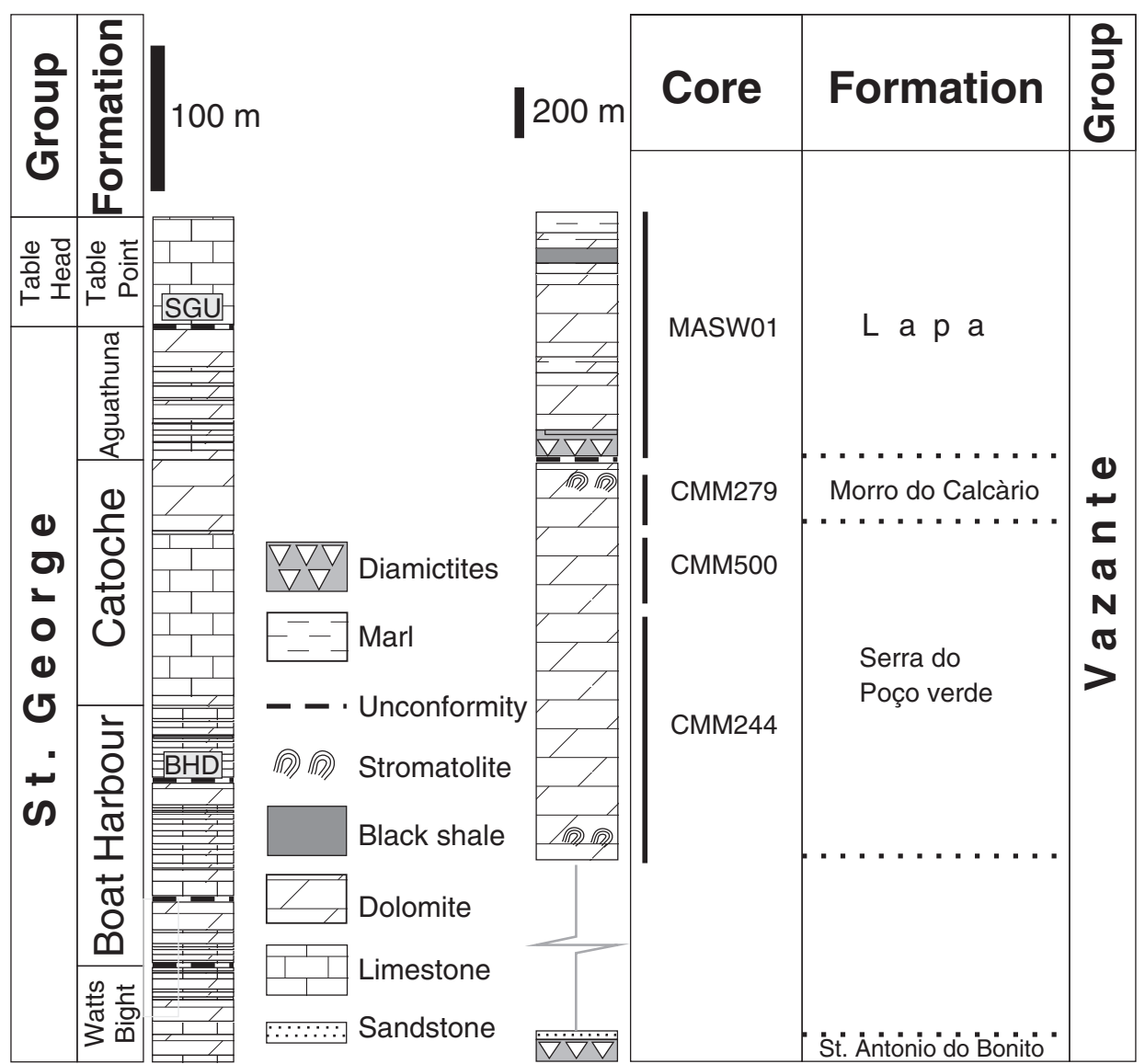

Fig. 1. Stratigraphic framework of the sequences from which samples was collected (modified from Azmy et al., 2008b; Azmy and Lavoie, 2009).

an Archean-Paleoproterozoic basement, which are overlain by wellpreserved Meso- and Neoproterozoic sedimentary strata. The present configuration of the SFC is believed to have been shaped by the Brazilian-Pan African Orogeny (Misi et al., 2007) that climaxed 600-550 Ma ago. In the east part of the basin, the Vazante sediments (mainly carbonates, diamictites, and shales) are generally well preserved and little metamorphosed. The Vazante Group sediments are suggested to have been likely accumulated in a passive margin setting (cf. Dardenne, 2001; Azmy et al., 2008b).

The stratigraphy of the sequence (Fig. 1) has been studied in detail and refined by several authors (e.g., Misi et al., 2007 and more references therein). The Vazante rocks rests on a major glaciogenic unit, which constitutes the topmost part of the Santo Antônio do Bonito Formation (Dardenne, 2001), and also contains another younger distinguishable glaciomarine diamictite unit containing abundant organic-rich shale layers, near its top at the base of Lapa Formation (Fig. 1). The upper part, from which samples of the current study were collected, of the Vazante sequence consists, from top to bottom, of Lapa, Morro do Calcàrio, and Serra do Po o verde formations (Fig. 1). The upper Vazante Group carbonates are almost entirely dolomitized and dominated by organic-rich dolomicrites of microbialite precursor (Dardenne, 2001).

The examined Hansonburg MVT deposit (Fluorite) is hosted in the Council Springs Member of the Pennsylvanian Madera limestone, and is originally described by Kottlowski (1953).

\section{Petrography}

The carbonates of the current research were deposited in marine tropical environments and the nature of the sediments and their diagenetic history have been well established through earlier studies of their detailed petrographic and geochemical attributes (e.g., Azmy et al., 2001, 2006; Knight et al., 2007; Azmy et al., 2008a, 2008b; Knight et al., 2008; Edinger et al., 2008). The detailed petrographic description of samples and the related fluid inclusions in the diagenetic phases along with the microthermometric characteristics have been described and discussed extensively in earlier studies by Lane (1990), Azmy et al. (2001, 2006, 2008a, 2008b, 2009), Azmy and Conliffe (2010), and Azomani et al. (2013). Since gas composition of the fluid inclusions is the main focus of the current study, the petrographic description and homogenization temperatures $\left(\mathrm{T}_{h}\right)$ of the primary two-phase (vapor-liquid) fluid inclusions are summarized in Table 1. No measureable fluid inclusions were observed in the micritic phases and their fabric retention argues against significant re-equilibration with late burial (hydrothermal) diagenetic fluids. The other diagenetic carbonate phases, that had bigger crystals, contained mainly primary two-phase fluid inclusions (cf. Goldstein and Reynolds, 1994) and the petrographic features of the host dolomites do not show evidences that support re-dissolution and precipitation after formation. The lack of fractures around the inclusion argues for its primary nature and against fluid leaking (Fig. 2f). The measured inclusions were intentionally selected from those parallel to crystal facets but in some cases they were in clusters. No oil inclusions were observed among the measured two-phase inclusions.

The modern carbonate sample is taken from a well-preserved Recent aragonitic (A) coral in the Java Sea at Point Teluk Awur, near Jepara, Central Java (Azmy et al., 2008a; Edinger et al., 2008) and the X-ray image shows no hidden alterations (Fig. 2a). The altered lime mudstones (C1) in the investigated samples (Table 1, Fig. 2b) have micritic to near-micritic size $(4-10 \mu \mathrm{m})$ crystals with restricted 

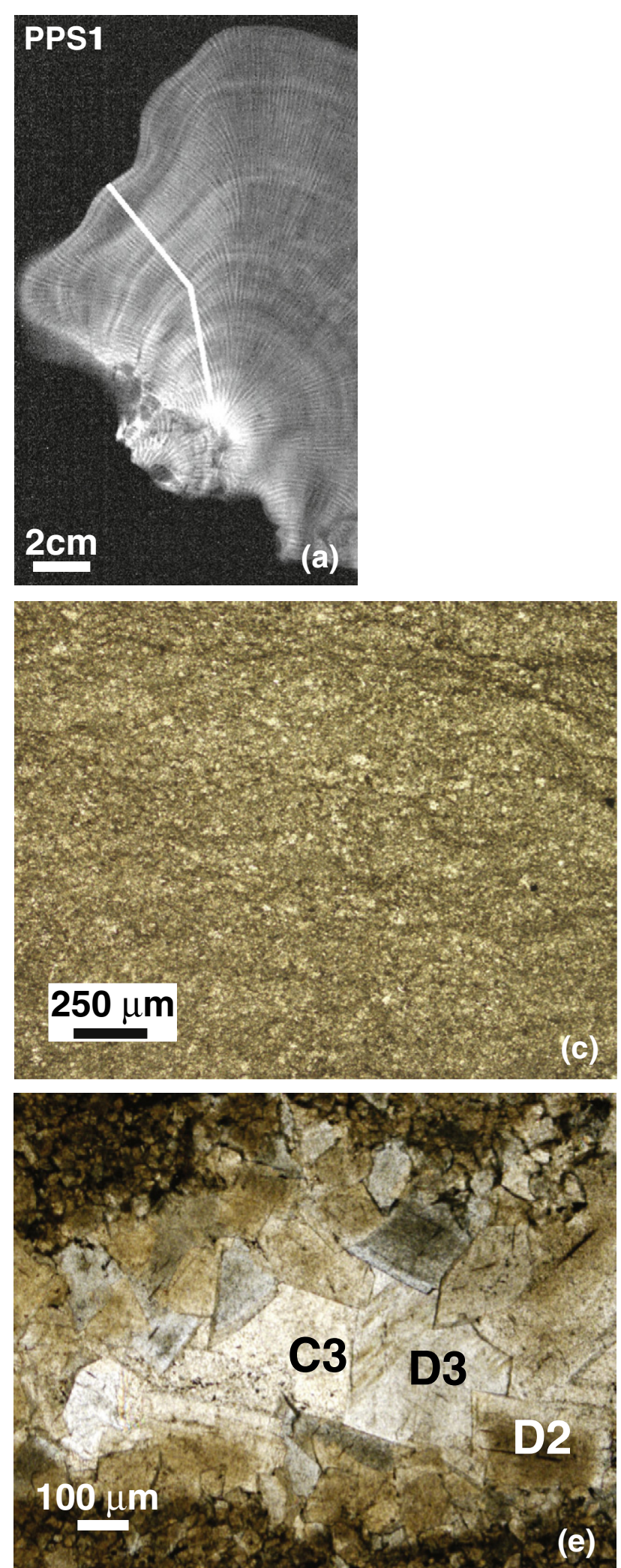
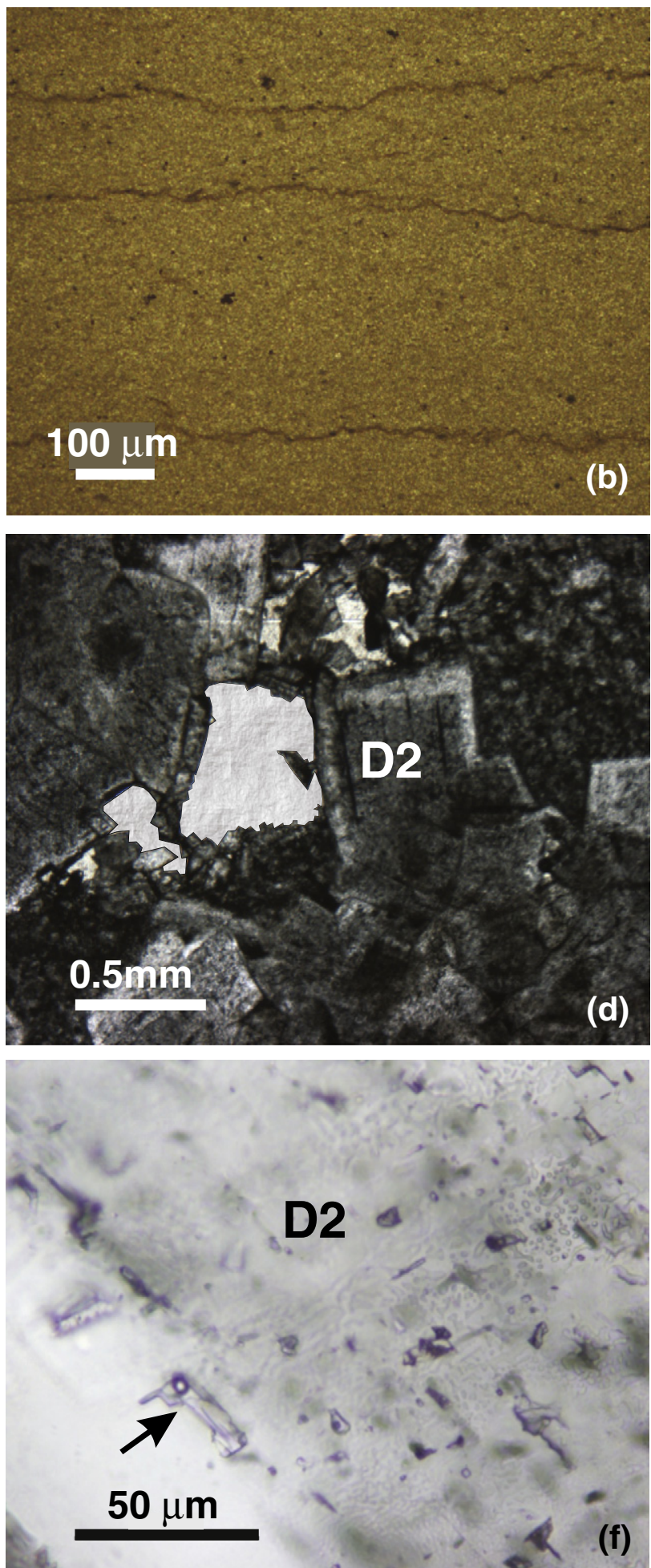

Fig. 2. Photos showing (a) the X-ray image of the investigated modern coral (Sample PPS11), (b) altered lime mudstones with restricted recrystallization (Sample R1-110), (c) D1 dolomicrite with fabric retention of precursor lime mud (Sample MAS 11), (d) D2 crystals with cloudy cores and clear rims (Sample P216), (e) saddle dolomite with undulose extinction (crossed Nichols; Sample BH34); and (f) primary two-phase fluid inclusions in D2 dolomite rhomb showing an inclusion elongated in the direction of growth of the dolomite rhomb (arrow) and absence of fractures around the inclusion argues.

recrystallization (e.g., Azmy et al., 2008a, 2009). Earlier studies of these limestones suggest that the preservation of sedimentary fabrics, such as microbial lamination (Fig. 2b), and red stain, using a mixture of Potassium ferricyanide and Alizarine red, suggest slightly Fe-rich cements that are consistent with meteoric alteration during early stage of diagenesis (e.g., Azmy et al., 2008c), which is also confirmed 
by their low $\mathrm{Sr}(<400 \mathrm{ppm})$ and high $\mathrm{Fe}(>500 \mathrm{ppm})$ contents (Table 1).

The dolomicrites (D1) are micritic to near-micritic (Table 1, Fig. 2c) similar to their lime mudstone precursor and exhibit fabric retention (e.g., Azmy et al., 2001, 2006, 2008c, 2009) that mimics their precursor (Fig. 2c). The petrographic and geochemical characteristics of the dolomicrites have been studied in detail by Azmy et al. (2006, 2008b, 2009), Conliffe et al. (2010), and Azomani et al. (2013). The relative preservation of fabric in the investigated dolomicrites (e.g., microbial lamination) and their low $\mathrm{Sr}$ contents (Table 1, Veizer et al., 1999), and also depleted $\delta^{18} \mathrm{O}$ signatures, compared with those suggested for the global meteoric and seawaters of their equivalent ages are consistent with an early stage dolomitization by modified seawater, likely mixed meteoric and marine waters (cf. Warren, 2000; Azmy et al., 2001, 2006, 2008b, 2009; Conliffe et al., 2010).

The hydrothermal dolomites from the St. George Group have generally 2 generations (Lonnee and Machel, 2006; Wierzbicki et al., 2006; Azmy et al., 2008c, 2009; Conliffe et al., 2009, 2010; Azmy and Conliffe, 2010; Conliffe et al., 2012), an early mid-burial crosscut by microstylolites (D2) and a late burial vug- and fracture filling (D3). The early D2 generation has coarse eu- to subhedral crystals (40 $200 \mu \mathrm{m}$ ) with cloudy cores and clear rims (Fig. 2d). The late-burial dolomite (D3) consists of coarse an- to subhedral saddle dolomite crystal ( $>0.5 \mathrm{~mm}$ ) with characteristic undulose extinction (Fig. 2e). The primary two-phase fluid inclusions (cf. Goldstein and Reynolds, 1994) in the hydrothermal dolomites (Fig. 2f) throughout the entire succession were $\sim 5$ to $7 \mu \mathrm{m}$ and provided mean $\mathrm{T}_{h}$ values generally between 75 and $141{ }^{\circ} \mathrm{C}$ (Table 1) and salinities between 18 and 25 eq. wt.\% NaCl. An earlier leach-analysis study on the St. George dolomites (Conliffe et al., 2010) suggested that they originated from locally circulated diagenetic fluids with homogenous composition rather than regional mixing with magmatic fluids (e.g., Lavoie et al., 2010). The latest pore- and fracture-filling cement is a hydrothermal coarse equant (up to $2 \mathrm{~cm}$ ) calcite (C3), which precipitated immediately after D3 (Fig. 2e) and has average $\mathrm{T}_{h}$ between 98 and $120{ }^{\circ} \mathrm{C}$ and salinities up to 25 eq. wt.\% $\mathrm{NaCl}$ (Azmy et al., 2009). The hydrothermal dolomites in the Vazante carbonates are also pore- and fracture filling and contained dominant primary two-phase fluid inclusions $(\sim 5 \mu \mathrm{m})$ that provided comparable $\mathrm{T}_{h}$ measurements between 120 and $130{ }^{\circ} \mathrm{C}$ (Azmy et al., 2001).

Fluorite crystals from the Hansonburg deposit are commonly $\sim 1 \mathrm{~cm}$ and colorless. The fluid inclusions are primary aqueousdominated (two-phase), ranging from 10 to $70 \mu \mathrm{m}$ in size but generally $\sim 30 \mu \mathrm{m}$. The typical $\mathrm{T}_{h}$ for the HF-1 lab standard is $\sim 180{ }^{\circ} \mathrm{C}$ and the $\mathrm{T}_{h}$ measurements range from 150 to $210^{\circ} \mathrm{C}$ and salinity from 15 to 20 eq. wt.\% $\mathrm{NaCl}$ (Hill et al., 2000) where mineralization is associated with higher $\mathrm{T}_{h}$ values.

\section{Results}

Table 1 summarizes the fluid inclusion gas analyses data, which are reported as weighted mean based on the burst size from several individual incremental crushes (detailed results of individual measurements are in the Supplementary Appendix 1) and is thus the equivalent of all the gases being released in one analysis. The term burst size refers to the current generated in the mass spectrometer and reflects the amount of volatiles released during crushing. Volatile composition is reported in mole percent ( $\mathrm{mol} \%$ ).

The Hansonburg HF-1 standard data (Table 1), generated by the incremental crush method, are in close agreement with the bulk data reported by Norman et al. (1985). However, our high-resolution incremental crush data do plot with a linear correlation of $\mathrm{CO}_{2} / \mathrm{CH}_{4}$ with $\mathrm{N}_{2} / \mathrm{Ar}$ (Fig. 3a) with more reduced fluids of lower $\mathrm{CO}_{2} / \mathrm{CH}_{4}$ ratios corresponding with higher $\mathrm{N}_{2} / \mathrm{Ar}$ ratios. Water is generally around $99.5 \mathrm{~mol} \%$ and $\mathrm{CO}_{2}$ ranges from 0.16 to $0.48 \mathrm{~mol} \%$ and $\mathrm{CH}_{4}$ from 0.01 to $0.39 \mathrm{~mol} \%$ with averages of 0.36 and $0.06 \mathrm{~mol} \%$, respectively. Notably, He is
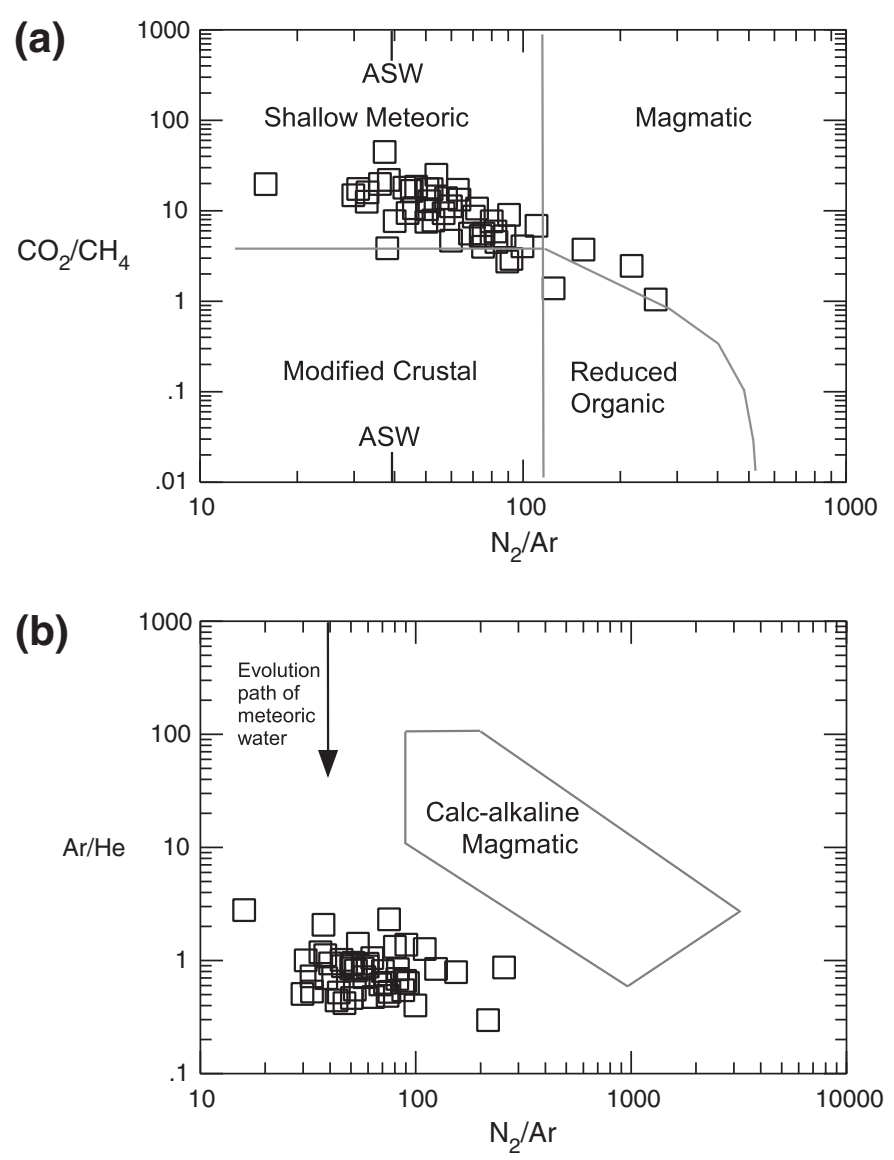

Fig. 3. Scatter diagrams of (a) $\mathrm{CO}_{2} / \mathrm{CH}_{4}$ versus $\mathrm{N}_{2} / \mathrm{Ar}$ and (b) $\mathrm{Ar} / \mathrm{He}$ versus $\mathrm{N}_{2} / \mathrm{Ar}$ for the Hansonburg MVT deposit (a lab standard) in New Mexico. The data plot outside the frame defined by calc-alkaline fluids (after Blamey and Norman, 2002; Blamey, 2012).

well elevated above air-saturated water and averages $0.0006 \mathrm{~mol} \%$ with $\mathrm{Ar} / \mathrm{He}$ ratios typically in the range of 0.4 to 2 (Fig. $3 \mathrm{~b}$ ). $\mathrm{N}_{2}$ is variable with an average of $0.03 \mathrm{~mol} \%$. The incremental crush data clearly show better resolution of heterogeneities than data acquired by the bulk thermal decrepitation method.

The Holocene coral has a weighted mean of $0.64 \mathrm{~mol} \% \mathrm{CO}_{2}$, $0.0016 \mathrm{~mol} \% \mathrm{CH}_{4}, 0.016 \mathrm{~mol}_{2} \mathrm{~N}_{2}$, and $0.036 \mathrm{~mol} \% \mathrm{O}_{2}$. The coral's $\mathrm{N}_{2} / \mathrm{Ar}$ ratio of 35.3 is in close agreement with air-saturated water whereas the $\mathrm{CO}_{2} / \mathrm{CH}_{4}$ ratio is $\sim 400$ mainly due to the low methane content (Fig. 4a) but the coral has the lowest He out of all the analyzed samples (Table 1, Figs 4 and 5).

The Mesoproterozoic (Vazante Group, Table 1) samples have the highest $\mathrm{H}_{2}$ content. They also have variable $\mathrm{CO}_{2} / \mathrm{CH}_{4}$ ratios and the highest $\mathrm{N}_{2} / \mathrm{Ar}$ ratios (Figs. 4 and 5) compared with the remaining samples. Their $\mathrm{CO}_{2}$ contents range from 6.2 to $14.1 \mathrm{~mol} \%$ with weighted mean ranging from 2.2 to $12.4 \mathrm{~mol} \%$ and their $\mathrm{CH}_{4}$ contents are also an order of magnitude lower, ranging from $\sim 0.06$ to $3.89 \mathrm{~mol} \%$ (Table 1 ).

The St. George Group carbonates have relatively homogenous fluid inclusion gas chemistry. Their $\mathrm{CO}_{2} / \mathrm{CH}_{4}$ ratios have a weighted mean ranging from 0.028 to 3.4 with the lowest values correlating with $\mathrm{C} 1$ whereas the highest values are D2 (Table 1, Figs. 4 and 5). In the same sequence the $\mathrm{N}_{2} / \mathrm{Ar}$ ratio ranges from 42.3 to 93.6 which approximates to air-saturated water (meteoric water) or slightly elevated above air-saturated water. However, the 4-series samples (Catoche Formation, Azomani et al., 2013) inclusion gases are anomalous and have $\mathrm{N}_{2} / \mathrm{Ar}$ ratios that exceed 100 (Table 1, Figs. 4 and 5). Their methane content ranges from 0.094 to $8.82 \mathrm{~mol} \%$ with the greatest values associated with the Catoche Formation. Nitrogen increases from 0.23 to 0.85 from C1 to D2 (Table 1 ). 

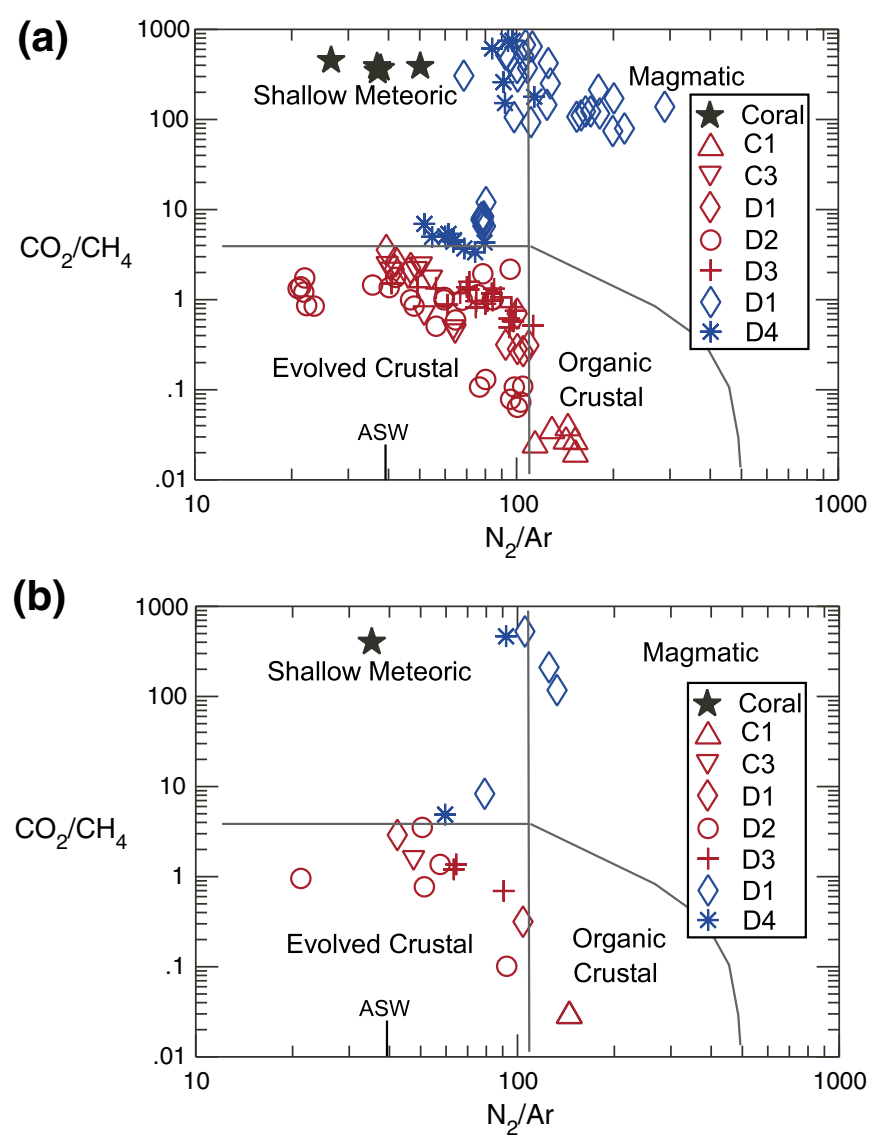

Fig. 4. Plot of $\mathrm{CO}_{2} / \mathrm{CH}_{4}$ versus $\mathrm{N}_{2} / \mathrm{Ar}$ for (a) several incremental crushes of each analyzed sample from the Vazante rocks of Brazil (blue), a Holocene coral from Indonesia (black), and diagenetic carbonates from western Newfoundland (red), and (b) ratios of weighted mean values for each sample.

Samples from the Vazante succession (KV-series) exhibit a high variability in gas composition. The $\mathrm{CO}_{2} / \mathrm{CH}_{4}$ weighted means vary from 8.3 to 522 with $\mathrm{CH}_{4}$ ranging from 0.01 to $0.42 \mathrm{~mol} \%$ whereas $\mathrm{CO}_{2}$ varies from 1.57 to $11.2 \mathrm{~mol} \%$. The $\mathrm{N}_{2} / \mathrm{Ar}$ ratios vary from 59.6 to 133 with D4 samples having the lowest ratios slightly greater than meteoric values whereas D1 samples have the greatest $\mathrm{N}_{2} / \mathrm{Ar}$ ratios (Table 1, Figs. 4 and 5).

The P216 and BH-series samples (St. George Group, Newfoundland) are relatively consistent with low $\mathrm{CO}_{2} / \mathrm{CH}_{4}$ that range from 0.7 to 1.6 . All these samples have relatively low $\mathrm{CO}_{2}$ ranging from 0.15 to $2.29 \mathrm{~mol} \%$ and relatively high $\mathrm{CH}_{4}$ varying from 0.09 to $1.7 \mathrm{~mol} \%$. The $\mathrm{N}_{2} / \mathrm{Ar}$ ratio varies from 48 to 59 which approximates to meteoric values. The gas/water ratio is the lowest for these samples and is only surpassed by the recent coral.

\section{Discussion}

The $\mathrm{CO}_{2} / \mathrm{CH}_{4}, \mathrm{Ar} / \mathrm{He}$ and $\mathrm{N}_{2} / \mathrm{Ar}$ ratios (Figs. 3-5) have been found to be an effective tool in the interpretation of the origin of geothermal fluids and recognizing sources with magmatic or meteoric volatiles (e.g., Blamey, 2012). The term air-saturated water (ASW) refers to water in equilibrium with atmosphere such that the gases partitioning between the water and atmosphere are in steady state. Under this condition, the $\mathrm{N}_{2} / \mathrm{Ar}$ ratio in water is 38 (Norman and Musgrave, 1994; Blamey, 2012). As meteoric water is sourced from ASW, the $\mathrm{N}_{2} / \mathrm{Ar}$ ratio of meteoric water is 38 , which allows the recognition of its signature after meteoric fluid has penetrated the subsurface. To our knowledge there are no discrimination diagrams based on fluid inclusion (a)

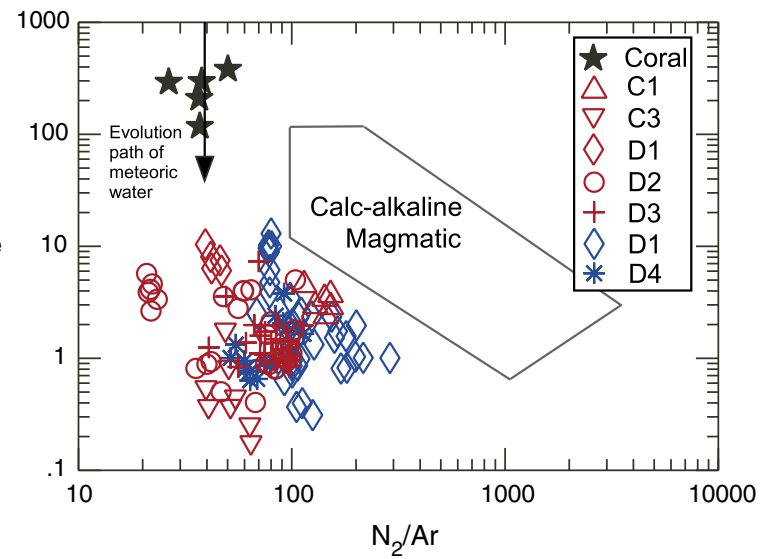

(b)

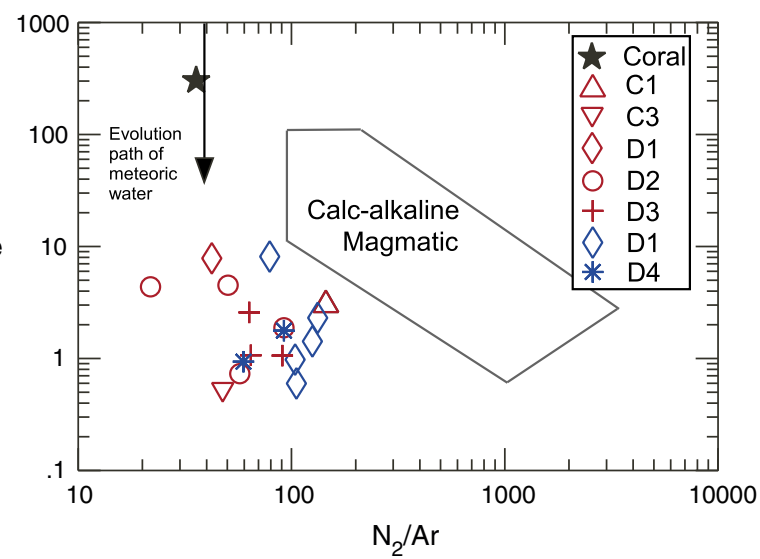

Fig. 5. Plot of $\mathrm{Ar} / \mathrm{He}$ versus $\mathrm{N}_{2} / \mathrm{Ar}$ for (a) several incremental crushes of each analyzed sample and (b) ratios of weighted mean values for each sample (slightly modified after Blamey and Norman, 2002). Color code as in Fig. 4.

gas ratios in the peer-reviewed literature that apply to diagenetic carbonate fluids.

The $\mathrm{N}_{2} /$ Ar ratios of many samples (Table 1 ), including the modern aragonitic coral, lime mudstones, dolomicrites and hydrothermal fracture-filling dolomites and calcites from the St. George Group are generally well below 100 except for some D1 samples (Fig. 4 and Table 1 ), which are consistent with the origin from non-magmatic fluids (Norman and Musgrave, 1994; Blamey, 2012), such as basinal fluids of mixed marine and meteoric waters that were circulated in the crust. This is consistent with conclusions from earlier stable isotope and trace element studies on the same rocks (Azmy et al., 2008c, 2009; Conliffe et al., 2009; Azmy and Conliffe, 2010; Azomani et al., 2013). A recent leach-analysis study on the St. George Group dolomites (Conliffe et al., 2010) supports the elimination of magmatic origin for the dolomitizing fluids. The modern aragonitic coral has $\mathrm{N}_{2} / \mathrm{Ar}$ and $\mathrm{CO}_{2} / \mathrm{CH}_{4}$ ratios that fall perfectly within the field identified for shallow meteoric/surface water (Fig. 4a, b), which is consistent with living in shallow surface water habitat of corals.

On the contrary, the samples of organic-rich dolomicrite of a microbialite precursor from the Mesoproterozoic Vazante succession (Azmy et al., 2001; Dardenne, 2001; Azmy et al. 2006, 2008b) have higher $\mathrm{N}_{2} / \mathrm{Ar}$ ratios ( $>100$; Table 1 ) compared with those from other dolomites, which place them abnormally within the field of magmatic origin for geothermal fluids despite the petrographic and other stable isotope and trace element geochemical evidences that reflect origin from non-magmatic (mixed marine and meteoric) fluids (e.g., sAzmy et al., 2001; Dardenne, 2001; Azmy et al., 2006). However, $\mathrm{N}_{2}$ can be released by the breakdown of protein compounds in geothermal systems 
thus increasing the $\mathrm{N}_{2} / \mathrm{Ar}$ ratio above 100 (Norman and Moore, 1999; Lowenstern and Janik, 2003) and the high organic contents in microbialitic dolomicrite are therefore most likely the reason for the elevated $\mathrm{N}_{2}$ contents.

The radiogenic decay of $\mathrm{K}$, particularly in Precambrian rocks, might contribute with some buildup of Ar (Faure and Mensing, 2005) but this effect should however be insignificant in pure carbonates, which usually have very small $\mathrm{K}$ contents (Veizer, 1983), due to the restricted replacement of $\mathrm{Ca}^{2+}$ by $\mathrm{K}^{+}$, and almost no siliciclastic inclusions. Furthermore, if radiogenic decay of $\mathrm{K}$ had contributed significantly to the ratios from the investigated carbonates, the Mesoproterozoic dolomites would have the higher $\mathrm{Ar}$ contents and lower $\mathrm{N}_{2} / \mathrm{Ar}$ ratios compared with the rest of the samples but this is not the case (Fig. 4a, c) but, on the contrary, the St. George carbonates have the higher Ar contents. Also, $\mathrm{N}_{2} / \mathrm{Ar}$ ratios that exceed 100 can be generated by the breakdown of protein that produces $\mathrm{N}_{2}$ (Norman and Moore, 1999) and is a likely explanation for some of the Hansonburg data. Analyses with high $\mathrm{CO}_{2} / \mathrm{CH}_{4}$ are therefore more oxidized and correspond with lowest $\mathrm{N}_{2} / \mathrm{Ar}$ ratios thereby exhibiting a negative correlation (Fig. 3a), which may be caused by reduced fluids inducing protein breakdown. Under protein breakdown conditions where nitrogen is produced, the Norman and Moore (1999) plot fails to take cognizance of organics and a $\mathrm{N}_{2}-\mathrm{Ar}-\mathrm{He}$ plot was therefore developed by Blamey and Norman (2002) to discriminate calc-alkaline magmatic fluids from organic-rich basinal fluids. By utilizing the $\mathrm{N}_{2}-\mathrm{Ar}-\mathrm{He}$ discrimination diagram (Fig. 5), the weighted-mean $\mathrm{Ar} / \mathrm{He}$ ratios of all investigated diagenetic carbonates vary between 0.52 and 8.1 and are much lower than magmatic fluid values, a range that is more typical of MVT fluids reported by Norman et al. (1985) and our HF-1 analyses. The data from the currently investigated carbonates plot outside the calc-alkaline magmatic field (Fig. 5) and accordingly a magmatic fluid contribution is very unlikely, which is also consistent with conclusions from their $\mathrm{N}_{2} / \mathrm{Ar}$ ratios. $\mathrm{The} \mathrm{Ar} / \mathrm{He}$ ratios are generally comparable with those of the basinal brines from the Hansonburg MVT deposit in New Mexico but the possible remaining argument is whether $\mathrm{N}_{2}$ or Ar has changed. Argon is essentially inert through the diagenetic environments, being neither added nor removed from diagenetic fluids but fixed at the interface of water and the atmosphere and is therefore expected to remain constant unless the water concentration changes. The only considered source of additional $\mathrm{Ar}$ is from K-bearing minerals that are subjected to temperatures above the closure temperatures of argon systematics, a scenario that requires a metamorphic realm and is therefore precluded here.

The studied samples have variable $\mathrm{CO}_{2}$ gas yields, typically 0.25 to $12.4 \mathrm{~mol} \%$. The high $\mathrm{CO}_{2}$ contents in the organic-rich dolomicrites could be attributed to oxidation of organic matter during early dolomitization which is suggested to have occurred at near surface temperature as supported by petrographic and geochemical evidence (e.g., Azmy et al., 2001; Dardenne, 2001; Azmy et al., 2006; Misi et al., 2007). On the other hand, the $0.64 \mathrm{~mol} \% \mathrm{CO}_{2}$ yield from the modern aragonitic corals (Fig. 4) is likely attributed to deposition of coral skeleton in shallow surface water where the $\mathrm{pCO}_{2}$ in sea surface water is maintained by photosynthesis.

The modern aragonitic coral provided the highest $\mathrm{Ar} / \mathrm{He}$ ratios followed by the Lower Ordovician carbonates and Mesoproterozoic dolomites (Fig. 5a, b; Table 1) and the high values are attributed to the low He in air-saturated water. On the other hand, radiogenic decay of $U$ produces He and this might increase He in the fluid inclusions, thus lowering the $\mathrm{Ar} / \mathrm{He}$ of the investigated ancient materials. However, the average contents of $U$ in St. George altered lime mudstones and hydrothermal cements are significantly low ( 0.1 to 0.5 ppm, Azmy et al., 2011) compared with those in hard rocks or siliciclastic sediments (Faure and Mensing, 2005), which makes the He contribution from radiogenic decay insignificant. This is consistent with comparable $\mathrm{Ar} / \mathrm{He}$ ratios of the investigated ancient carbonates from the Lower Ordovician (St. George Group) and Mesoproterozoic (Vazante succession), which show insignificant differences (Fig. 5).

\section{Conclusions}

Fluid-inclusion gas analysis of the investigated ancient marine carbonates confirms $\mathrm{N}_{2} / \mathrm{Ar}$ ratios that correspond to meteoric/modified meteoric (e.g., mixed marine-meteoric) origin consistent with early diagenetic meteoric environment settings, which supports the conclusions from earlier detailed petrographic, stable isotope, and leach analysis studies on those carbonates. The values of gas ratios obtained from currently investigated dolomite samples do not match $\mathrm{N}_{2}-\mathrm{Ar}-\mathrm{He}$ values normally associated with magmatic volatiles and thus suggesting basinal dolomitizing fluids that likely originated from modified seawater (mixed meteoric and seawaters) that were circulated in the crust during the burial history of sediments. The $\mathrm{Ar} / \mathrm{He}$ and $\mathrm{N}_{2} / \mathrm{Ar}$ correlations suggest that similar fluids are present in both basinal brines from MVT deposits and diagenetic fluids. In addition, high $\mathrm{N}_{2}$ in some diagenetic fluids may not be sourced from magmatic fluids but from the breakdown of protein under reducing conditions particularly in case of organic-rich carbonates.

Inputs of $\mathrm{Ar}$ and $\mathrm{He}$ from radiogenic decay of $\mathrm{K}$ and $\mathrm{U}$, respectively, seem to be insignificant in ancient carbonates, including those from the Mesoproterozoic, since the concentrations of those radioactive elements in carbonates are significantly low compared with their hard rock and siliciclastic counterparts.

Thus, the fluid-inclusion gas ratio analysis is consistent to be a reliable confirmatory tool for the identification of origin of diagenetic carbonates and their parent fluids.

Supplementary data to this article can be found online at http:// dx.doi.org/10.1016/j.chemgeo.2013.04.011.

\section{Acknowledgment}

The authors wish to thank two anonymous reviewers for their constructive reviews. Also, efforts of Dr. David Hilton (editor-in-chief) are much appreciated. Uwe Brand is also thanked for his constructive comments during the preparation of this manuscript. This project was supported by funding (to Karem Azmy) from the Petroleum Exploration Enhancement Program (PEEP).

\section{References}

Azmy, K., Conliffe, J., 2010. Dolomitization of the lower St. George Group on the Northern Peninsula in western Newfoundland: implications for lateral distribution of porosity. Bulletin of Canadian Petroleum Geology 58 (4), 1-14.

Azmy, K., Lavoie, D., 2009. High-resolution isotope stratigraphy of the Lower Ordovician St. George Group of western Newfoundland, Canada: implications for global correlation, Canadian Journal of Earth Sciences 46, 403-423.

Azmy, K., Veizer, J., Misi, R., De Olivia, T., Sanches, A.L., Dardenne, M., 2001. Dolomitization and isotope stratigraphy of the Neoproterozoic carbonate of Vazante Formation, Săo Francisco Basin, Brazil. Precambrian Research 112, 303-329.

Azmy, K., Kaufman, A.J., Misi, A., Oliveira, T.F., 2006. Isotope stratigraphy of the Lapa Formation, São Francisco Basin, Brazil: implications for Late Neoproterozoic glacial events in South America. Precambrian Research 149, 231-248.

Azmy, K., Edinger, E., Lundberg, L., Diegor, W., 2008a. Sr/Ca Records in Modern and Holocene Porites lobata from Java Sea: implications for paleotemperatures. International Journal of Earth Sciences (Geologische Rundschau). http://dx.doi.org/ 10.1007/s00531-008-0383-3.

Azmy, K., Kendall, B., Creaser, R.A., Heaman, L., de Oliveira, T.F., 2008b. Global Correlation of the Vazante Group, São Francisco Basin, Brazil: Re-Os and U-Pb radiometric age constraints. Precambrian Research 164, 160-172.

Azmy, K., Lavoie, D., Knight, I., Chi, G., 2008c. Dolomitization of the Lower Ordovician Aguathuna Formation carbonates, Port au Port Peninsula, western Newfoundland, Canada: implications for a hydrocarbon reservoir. Canadian Journal of Earth Sciences 45, 795-813.

Azmy, K., Knight, I., Lavoie, D., Chi, G., 2009. Origin of the Boat Harbour dolomites of the St. George Group in western Newfoundland, Canada: implications for porosity controls. Bulletin of Canadian Petroleum Geology 57, 81-104.

Azmy, K., Brand, U., Sylvester, P., Gleeson, S., Logan, A., Bitner, M.A., 2011. Biogenic low-Mg calcite (brachiopods): proxy of seawater-REE composition, natural processes and diagenetic alteration. Chemical Geology 280, 180-190.

Azomani, E., Azmy, K., Blamey, N.J.F., Brand, U., Al-Aasm, I., 2013. Origin of Lower Ordovician dolomites in eastern Laurentia: controls on porosity and implications from geochemistry. Marine and Petroleum Geology 40, 99-114.

Blamey, N.J.F., 2012. Composition and evolution of crustal, geothermal and hydrothermal fluids interpreted using quantitative fluid inclusion gas analysis. Journal of Geochemical Exploration 116-117, 17-27. 
Blamey, N.J.F., Norman, D.I., 2002. New interpretations of geothermal volatiles: $\mathrm{Ar} / \mathrm{He}$ and $\mathrm{N}_{2} / \mathrm{Ar}$ ratios - better indicator of magmatic volatiles, and equilibrium gas geothermometry. Proceedings, Twenty-seventh Workshop of Geothermal Reservoir Engineering, Stanford University, Stanford, California, January 28-30, CD.

Blamey, N.J.F., Parnell, J., Longerich, H.P., 2012. Understanding detection limits in fluid inclusion analysis using an incremental crush fast scan method for planetary science. 43rd Lunar Planetary Science Conference, Houston, abstract \#1035.

Bray, C.J., Spooner, E.T.C., Thomas, A.V., 1991. Fluid inclusion volatile analysis by heated crushing, on-line gas chromatography; applications to Archean fluids. Journal of Geochemical Exploration 42, 167-193.

Chi, G., Savard, M.M., 1997. Sources of basinal and Mississippi Valley-type mineralizing brines: mixing of evaporated seawater and halite-dissolution brine. Chemical Geology 143, 121-125.

Conliffe, J., Azmy, K., Knight, I., Lavoie, D., 2009. Dolomitization in the Lower Ordovician Watts Bight Formation of the St Georges Group, Western Newfoundland. Canadian Journal of Earth Sciences 46, 247-261.

Conliffe, J., Azmy, K., Gleeson, S.A., Lavoie, D., 2010. Fluids associated with hydrothermal dolomitization in St. George Group, western Newfoundland, Canada. Geofluids 9, 1-16.

Conliffe, J., Azmy, K., Greene, M., 2012. Hydrothermal dolomites in the Lower Ordovician Catoche Formation. Marine and Petroleum Geology 30, 161-173.

Dardenne, M.A., 2001. Lithostratigraphic sedimentary sequences of the Vazante Group. IGCP 450 Proterozoic sediment-hosted base metal deposits of western Gondwana (Abstr.). Belo Horizonte, Brazil, pp. 48-50.

Edinger, E.N., Azmy, K., Diegor, W., Siregar, P.R., 2008. Heavy metal contamination from gold mining recorded in Porites lobata skeletons, Buyat-Ratototok district, North Sulawesi, Indonesia. Marine Pollution Bulletin 56, 1553-1569.

Faure, G., Mensing, T.M., 2005. Isotopes: Principles and Applications, 3rd ed. John Willey and Sons Inc., Hoboken, New Jersey (897 pp.).

Goldstein, R.H., Reynolds, T.J., 1994. Systematics of fluid inclusions in diagenetic minerals. Short course, 31. SEPM (Society for Sedimentary Geology) (199 pp.).

Hill, G.T., Campbell, A.R., Kyle, P.R., 2000. Geochemistry of southwestern New Mexico fluorite occurrences implications for precious metals exploration in fluoritebearing systems. Journal of Geochemical Exploration 68, 1-20.

Knight, I., James, N.P., 1987. Stratigraphy of the St. George Group (Lower Ordovician), western Newfoundland: the interaction between eustasy and tectonics. Canadian Journal of Earth Sciences 24 (1987), 1927-1952.

Knight, I., Azmy, K., Greene, M., Lavoie, D., 2007. Lithostratigraphic setting of diagenetic, isotopic, and geochemistry studies of Ibexian and Whiterockian carbonates of the St. George and Table Head groups in western Newfoundland: Current Research Newfoundland and Labrador Department of Natural Resources Geological Survey, Report 07-1, pp. 55-84

Knight, I., Azmy, K., Boyce, D., Lavoie, D., 2008. Tremadocian carbonates of the lower St George Group, Port au Port Peninsula, western Newfoundland: lithostratigraphic setting of diagenetic, isotopic, and geochemistry studies. Current Research Newfoundland and Labrador Department of Natural Resources Geological Survey, Report 08-1, pp. 1-43.

Kottlowski, F.F., 1953. Geology and ore deposits of the Hansonburg mining district, Socorro County, New Mexico. New Mexico Bureau of Mines and Mineral Resources, Circular 23.

Lane, T.E., 1990. Dolomitization, brecciation and zinc mineralization and their paragenetic, stratigraphic and structural relationships in the upper St. George Group (Ordovician) at Daniel's Harbour, western Newfoundland. (Unpublished PhD Thesis) Memorial University of Newfoundland (496 pp.).

Lavoie, D., Chi, G., Brennan-Alpert, P., Betrand, R., 2005. Hydrothermal dolomitization in the Lower Ordovician Romaine Formation of the Anticosti Basin: significance for hydrocarbon exploration. Bulletin of Canadian Petroleum Geology 53, 256-269.
Lavoie, D., Chi, G., Urbatsch, M., Davis, W.J., 2010. Massive dolomitization of a pinnacle reef in the Lower Devonian West Point Formation (Gaspé Peninsula, Quebec): an extreme case of hydrothermal dolomitization through fault-focused circulation of magmatic fluids. American Association of Petroleum Geologists Bulletin 94, 513-531.

Lonnee, J., Machel, H.G., 2006. Pervasive dolomitization with subsequent hydrotherma alteration in the Clarke Lake gas field, Middle Devonian Slave Point Formation, British Columbia, Canada. American Association of Petroleum Geologists Bulletin 90, 1739-1761.

Lowenstern, J.B., Janik, C.J., 2003. The origins of reservoir liquids and vapors from the geysers geothermal field, California. Society of Economic Geologists, Special Publication 10, 181-196.

Misi, A., Kaufman, A.J., Veizer, J., Powis, K., Azmy, K., Boggiani, P.C., Gaucher, C., Teixeira, J.B.G., Sanches, A.L., Iyer, S.S., 2007. Chemostratigraphic correlation of Neoproterozoic successions in South America. Chemical Geology 237, 161-185.

Moore, J.N., Norman, D.I., Kennedy, B.M., 1997. Fluid inclusion gas compositions from an active magmatic-hydrothermal system: a case study of The Geysers geotherma field, USA. Chemical Geology 173, 3-30.

Norman, D.I., Blamey, N.J.F., 2001. Quantitative gas analysis of fluid inclusion volatiles by a two mass spectrometer system. Proceedings European Current Research on Fluid Inclusions, vol. 16, pp. 341-344 (Porto, Portugal).

Norman, D.I., Moore, J.N., 1997. Gaseous species in fluid inclusions: a fluid tracer and indicator of fluid processes. Proceedings, European Current Research on Fluid Inclusions, vol. 14, pp. 243-244 (Nancy, France).

Norman, D.I., Moore, J.N., 1999. Methane and excess $\mathrm{N}_{2}$ and $\mathrm{Ar}$ in geothermal fluid inclusions. Proceedings, Twenty-fourth Workshop of Geothermal Reservoir Engineering, Stanford University, Stanford, California, January 22-24, pp. 233-240.

Norman, D.I., Musgrave, J.A., 1994. $\mathrm{N}_{2}-\mathrm{Ar}-\mathrm{He}$ compositions in fluid inclusions: indicators of fluid source. Geochimica et Cosmochimica Acta 58, 1119-1131.

Norman, D.I., Ting, W., Putnam, B.R., Smith, R.W., 1985. Mineralization of the Hansonburg Mississippi-type deposit New Mexico: insight from composition of gases in fluid inclusions. The Canadian Mineralogist 23, 353-368.

Norman, D.I., Blamey, N.J.F., Kurilovich, L., 2002. New applications of geothermal gas analysis to exploration. Transactions of the Geothermal Resources Council 26, 345-353.

Parry, W.T., Blamey, N.J.F., 2010. Fault fluid composition from fluid inclusion measurements, Laramide Age Uinta Thrust Fault, Utah. Chemical Geology 278, 105-119.

Roedder, E., 1984. Fluid inclusions. Mineralogical Society of America. Reviews in Mineralogy 12 (644 pp.).

Stoffel, B., Appold, M.S., Wilkinson, J.J., McClean, N.A., Jefferies, T.E., 2008. Geochemistry and evolution of Mississippi Valley-type mineralizing brines from the Tri-State and Northern Arkansas Districts determined by LA-ICP-MS microanalysis of fluid inclusions. Economic Geology 103, 1435-1441.

Tucker, M.E., Wright, V.P., 1990. Carbonate Sedimentology. Blackwell Scientific Publications (482 pp.).

Veizer, J., Ala, D., Azmy, K., Bruckschen, P., Bruhn, F., Buhl, D., Carden, G., Diener, A., Ebneth, S., Goddris, Y., Jasper, T., Korte, C., Pawellek, F., Podlaha, O., Strauss, H., 1999. ${ }^{87} \mathrm{Sr} /{ }^{86} \mathrm{Sr}$, $\delta^{18} \mathrm{O}$ and $\delta^{13} \mathrm{C}$ evolution of Phanerozoic seawater. Chemical Geology 161, 59-88.

Veizer, J., 1983. Chemical diagenesis of carbonates: theory and application of trace element technique. In: Arthur, M.A., Anderson, T.F., Kaplan, I.R., Veizer, J., Land, L.S. (Eds.), Stable Isotopes in Sedimentary Geology. Society of Economic Paleontologists and Mineralogists (SEPM) Short Course Notes, 10. III-1-III-100.

Warren, J., 2000. Dolomite: occurrence, evolution, and economically important associations. Earth-Science Reviews 52, 1-81.

Wierzbicki, R., Dravis, J.J., Al-Aasm, I., Harland, N., 2006. Burial dolomitization and dissolution of Upper Jurassic Abenaki platform carbonates, Deep Panuke reservoir, Nova Scotia, Canada. American Association of Petroleum Geologists Bulletin 90, 1843-1861. 